\title{
Evaluation of the Effects of Liquefaction on Concrete Pile
}

\author{
Asha Waliitagi \\ Department of Civil Engineering, \\ KLEMSSCET, Belgaum, \\ Karnataka, India
}

\author{
Dr. S. V. Itti \\ Department of Civil Engineering, \\ KLEMSSCET, Belgaum, \\ Karnataka, India
}

\begin{abstract}
ANSYS is finite element software. In the present work finite element model is employed herein to determine the displacements in a concrete pile under liquefiable and nonliquefiable soils. In the present study parameters used are the variation in stiffness, different soil layers and residual strength of the liquefied soil. The different soil layers used are dense sand and loose sand. The study shows that the total displacement increasing with respect to depth of the concrete pile. The displacement of concrete pile is more for which is having liquefiable soil compared to nonliquefiable soil because when liquefaction takes place soil loses its strength and stiffness therefore such piles will have more displacement.
\end{abstract}

Keywords- Pile, Liquefaction, Stiffness, Displacements, ANSYS.

\section{INTRODUCTION}

Pile foundations are the most popular form of deep foundations and pile foundations are the part of the structure used for both onshore and offshore structures. They are often used to transfer large loads from the superstructure into deeper, competent soil layers particularly when the structure is to be located on shallow, weak soil layers. Piles are long and slender members which transfer the load to deeper soil or rock of high bearing capacity avoiding shallow soil of low bearing capacity the main types of materials used for piles are wood, steel, concrete. Piles made from these materials are driven, drilled or jacked into the ground and connected to pile caps. Under liquefiable and nonliquefiable soils using the advanced finite element software package ANSYS.

\subsection{Pile Behavior under Earthquake Loading:}

The loading requirements imposed by seismic events on piles require different geotechnical and structural design of these elements compared with the static design of pile under static loading. Let us consider the case of pile foundations in level ground comprising a soft, horizontal soil layer in which no soil liquefaction occurs, overlying a stiff, horizontal soil layer. The pile foundation passes through the soft layer and rests on the stiff soil layer.

The earthquake motion can be transmitted from the stiff soil stratum into the softer layer and this motion can be amplified as it propagates through the softer layer, is transferred to the pile and onto the superstructure. This sets up structural vibration in the superstructure. As these vibrations are being set up in the superstructure, it will impose inertial loading on the pile cap. This inertial load has to be carried by the piles. If the inertial load is large, then piles can suffer significant lateral displacements. Further, depending on the stiffness of the superstructure and the pile cap's bearing capacity, the pile cap can either be prevented from suffering any rotation or some rotation can occur. If the pile cap rotations are prevented then the piles will undergo elastic bending and in extreme cases plastic hinges can form at the pile/pile cap. On the other hand, if the pile cap can undergo some rotation, then the piles will suffer elastic bending but the pattern of bending is opposition to the previous case. These types of behavior will be dominated by the stiffness of the shallow soil layer as the lateral inertial load on the piles will only displace the soil in this region. If the shallow layers in this region are soft, this can be accomplished easily. On the other hand, if the shallow layer below the pile cap comprises stiffer/competent soil then the lateral displacement of piles and the rotation of the pile cap will be smaller, but the piles may attract large lateral loads that oppose the inertial loads due to mobilization of the passive soil pressures in this region.

Pile foundations are primarily designed to transfer vertical loads from the superstructure to the bearing stratum. For this reason, piles are relatively vulnerable to lateral loads such as those imposed by ground shaking during strong earthquakes. In the case of soil liquefaction, this vulnerability is particularly pronounced since the loss of strength and stiffness in the liquefied soil results in a near complete loss of lateral support for the embedded piles. It is known from previous earthquakes that liquefaction can cause very large loads on pile foundations, both from inertial loads from the superstructure and from lateral displacements of liquefied soil. The extensive damage and failure of piles have affected numerous bridges, buildings and storage tanks in the past.

\section{NUMERICAL STUDY}

The finite element analysis software ANSYS, is used in this study. The pile is modeled using a 20-node brick element which is solid 186 elements. A fixed support condition is provided at the bottom of pile. For the concrete pile, the young's modulus is $27386 \mathrm{MPa}$ and Poisson's ratio is 0.3 . 


\subsection{Verification and Validation}

Consider pile foundations are to be designed for a bridge pier. The axial load on the pile cap from the pier is expected to be $7580 \mathrm{kN}$. Considering $1 \mathrm{~m}$ diameter of pile and $16 \mathrm{~m}$ length, $8 \mathrm{~m}$ thick loose sand layer and $8 \mathrm{~m}$ thick dense sand layer. The water table is expected to be at the ground level. The saturated unit weight of the loose sand layer is $17 \mathrm{kN} / \mathrm{m}^{3}$ and that of the dense sand is $19 \mathrm{kN} / \mathrm{m}^{3}$. The critical state friction angle for both these soils is initially taken to be $32^{\circ}$. The design earthquake is an L1 event, having a magnitude $M=6$ generating a peak ground acceleration of $0.2 \mathrm{~g}$.

Step 1: Pre Analysis \& Start-Up

$>$ To calculate the maximum displacement for nonliquefiable soil.

Table1: Concrete Pile Properties

\begin{tabular}{|l|l|l|l|}
\hline Diameter $(\mathrm{m})$ & $\begin{array}{l}\text { Length } \\
\mathrm{m})\end{array}$ & $\begin{array}{l}\text { EI } \\
\left(\mathrm{KNm}^{2}\right)\end{array}$ & $\begin{array}{l}\text { Yield Stress } \\
(\mathrm{Mpa})\end{array}$ \\
\hline 1 & 16 & $953.75 \times 10^{3}$ & 415 \\
\hline
\end{tabular}

Preliminary design of piles under static loading:

Axial capacity of a single pile

For a single pile, the axial load carrying capacity can be written from

Vertical equilibrium considerations as

$\mathrm{Q}_{\mathrm{u}}=\mathrm{Q}_{\mathrm{b}}+\mathrm{Q}_{\mathrm{s}}$

Where $Q_{u}$ - axial capacity of the pile

$\mathrm{Q}_{\mathrm{b}}$ - base resistance at the pile tip

$\mathrm{Q}_{\mathrm{s}}$ - Shaft friction of the pile

End bearing;

$\mathrm{Q}_{\mathrm{b}}=\mathrm{A}_{\mathrm{b}} \sigma_{\mathrm{b}}\left(\mathrm{N}_{\mathrm{q}}-1\right)$

Where, $A_{b}=$ Pile base area

$\sigma_{\mathrm{b}}=$ Effective overburden pressure

$\mathrm{Nq}$ - bearing capacity factor that can be estimated using Fig. 1.2 below, based on the angle of shearing resistance of the soil.

$\mathrm{A}_{\mathrm{b}}=(\Pi / 4) \times 1^{2}=0.7854 \mathrm{~m}^{2}$

$\sigma \mathrm{b}=(17 \times 8)+(19 \times 8)-(16 \times 10)=128 \mathrm{KN} / \mathrm{m}^{2}$

For a critical state friction angle of $32^{\circ}$ for the dense sand, the value of $\mathrm{N}_{\text {. can he taken as }} \Delta \mathrm{n}$ from fio $52^{[13]}$

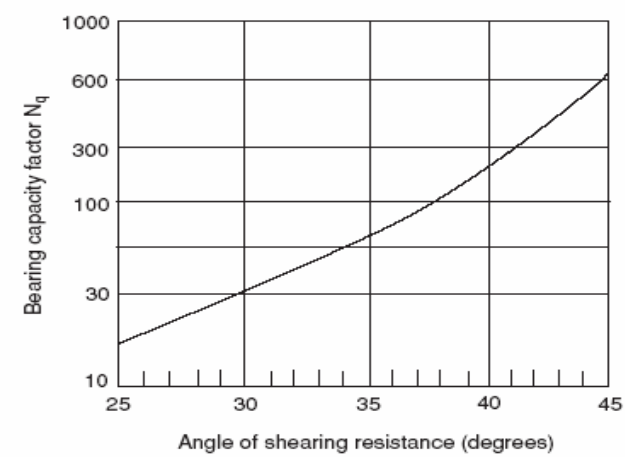

Figure 1. Bearing capacity factor $\mathrm{N}_{\mathrm{q}}$ for deep foundations.

Therefore the base resistance at the pile tip is

$\mathrm{Q}_{\mathrm{b}}=0.7854 \times 128 \times(40-1)$

$\mathrm{Q}_{\mathrm{b}}=3920.72 \mathrm{KN}$

Shaft friction of the pile

The shaft capacity may be obtained by estimating the shear stress generated along the shaft which can be calculated as $\tau=K \sigma^{\prime} \tan \delta_{\mathrm{cv}}$

where $K_{\mathrm{s}}-$ is a earth pressure coefficient $\sigma^{\prime}-$ is effective vertical stress at a given elevation

$\delta_{\mathrm{cv}}$ - friction angle between the pile material and the soil.

$K s$ depend on type of pile and installation method (driven or cast in situ piles). Broms (1966) related the values of $K_{\mathrm{s}}$ and $\delta_{\mathrm{cv}}$ to the angle of shearing resistance of the soil $\varphi$ as shown in Table 5.4

In order to obtain the shaft capacity due to skin friction, the shear stress must be integrated over the surface area of the pile using the following equation,

$$
Q_{s}=2 \pi r \times \int_{0}^{L} \tau_{s}
$$

Where $r$ is the pile radius

$\mathrm{L}$ is the length of the pile.

Table 2. Values of earth pressure coefficient $K s$ and pile-soil friction angle $\delta^{[6]}$

\begin{tabular}{|l|l|l|l|}
\hline Pile Material & $\delta_{\mathrm{cv}}$ & Ks \\
\cline { 3 - 4 } & $\begin{array}{l}\text { Low relative } \\
\text { density }\end{array}$ & $\begin{array}{l}\text { High relative } \\
\text { density }\end{array}$ \\
\hline Steel & $20^{\circ}$ & 0.5 & 1.0 \\
\hline Concrete & $0.75 \varphi^{\prime}$ & 1.0 & 2.0 \\
\hline Wood & $0.66 \varphi^{\prime}$ & 1.5 & 4.0 \\
\hline
\end{tabular}

The friction angle between pile \&the sand is assumed to be $20^{\circ}$.

For concrete $\delta_{\mathrm{cv}}=0.75 \times 32^{\circ}=24^{\circ}$

Shear stress at any depth $\mathrm{z}$ in the medium silty sand \& the dense sand layers is calculated below

$\tau_{\mathrm{s}}=1.0 \mathrm{x}(17-10) \mathrm{z} \tan \left(24^{\circ}\right)=3.116 \mathrm{z}$

$\tau_{\mathrm{s}}=2.0 \mathrm{x}(19-10) \mathrm{z} \tan \left(24^{\circ}\right)=4.01 \mathrm{z}$

Therefore the shaft resistance is

$\mathrm{Qs}=\Pi \mathrm{x} 1\left(\int 3.116 \mathrm{z} \mathrm{dz}(0,8)+\int 4.01 \mathrm{z} \mathrm{dz}(8,16)\right)$

$\mathrm{Qs}=2328.9 \mathrm{KN}$

Therefore axial capacity of the pile is

$\mathrm{Qu}=3920.72+2328.9$

$\mathrm{Qu}=6249.62=6250 \mathrm{KN}$

Consider Factor of safety $=2.5$

Working load $=6250 / 2.5=2500$

Therefore number of piles required

$=7850 / 2500=3.03$

Load on each pile $=7850 / 3=2550 \mathrm{kN}$

Soil stiffness \& Natural frequency

Assume void ratio of the silty sand layer e $=0.9$

Void ratio of the dense sand layer e $=0.6$

The vertical effective stress at $2 \mathrm{~m}$ depth $\sigma$ ' ${ }^{\prime}$ o $=5 \mathrm{KPa}$

Assuming the coefficient of earth pressure at rest

$\mathrm{K}_{\mathrm{O}}=0.46$

The main effective confining pressure $\mathrm{p}^{\prime}$ is

$\mathrm{p}^{\prime}=\left(\left(1+2 \mathrm{k}_{\mathrm{o}}\right) / 3\right) \sigma^{\prime}$ vo

$\mathrm{p}^{\prime}=((1+2 \times 0.46) / 3) \times 5=3.2 \mathrm{KPa}$

The small strain shear modulus of the loose sand layer is

Go $=100\left((3-\mathrm{e})^{2 /(1+e)}\right) \bigvee^{\prime} \mathrm{p}^{\prime}$

Go $=100\left((3-0.85)^{2} /(1+0.85)\right) \sqrt{ }(3.2 / 1000)$

$=20.365 \mathrm{MPa}$

$\mathrm{Gs}=$ Shear modulus $=0.2 \mathrm{Go}$

$=0.2 \times 20.365=4.07 \mathrm{MPa}$

Young's modulus can be calculated as Es $=2 \mathrm{Gs}(1+\mathrm{v})$

$(\mathrm{v}=$ poison's ratio is 0.3 )

Es $=2 \times 4.07 \times(1+0.3)=10.59 \mathrm{MPa}$

The stiffness of each pile in the pile group is determined by considering eurocode 8 provisions ${ }^{[7]}$. 
Using table 2.3 , p no-77 \& assuming a squre root variation of stiffness with depth for the loose sand ${ }^{[6]}$.

The horizontal stiffness is $\mathrm{K}_{\mathrm{h}}=0.79 \mathrm{D} \mathrm{E}_{\mathrm{sd}}\left(\mathrm{E}_{\mathrm{p}} / \mathrm{E}_{\mathrm{sd}}\right)^{0.28}$

$\mathrm{K}_{\mathrm{h}}=0.79 \times 1 \times 10.59 \times(27386 / 10.59)^{0.28}$

$\mathrm{K}_{\mathrm{h}}=75.52 \times 10^{3} \mathrm{KN} / \mathrm{m}$

The natural frequency of the pile group is:

$\mathrm{f}_{\mathrm{p}}=(1 / 2 \Pi)\left(\sqrt{ }\left(4 \times 75.52 \times 10^{3} / 2550\right)\right)=1.733 \mathrm{HZ}$

Natural period is $\mathrm{N}=1 / \mathrm{f}_{\mathrm{p}}=0.577$

From fig 6.3 from eurocode 8 provisions ${ }^{[17]}$,for a time period is 0.56 seconds, the spectral acceleration is $2.13 \mathrm{a}_{\mathrm{g}}$

The Response acceleration of the pile group will therefore be:

$2.13 \times 0.2 \times 9.81=4.179 \mathrm{~m} / \mathrm{s}^{2}$

The horizontal inertial load on the pile group will be

$\mathrm{H}=2550 \times 4.179=10656.6 \mathrm{KN}$

The moment load on the pile group will be

$\mathrm{M}=10656.6 \times 4.179 \times 2=89069.17 \mathrm{KNm}$

The peak horizontal displacement $\delta_{\mathrm{h}}$ during the inertial response of the pile group is:

$\delta_{\mathrm{h}}=\mathrm{H} / 4 \mathrm{~K}_{\mathrm{h}}=10656.6 / 4 \times 75.52 \times 10^{3}$

$\delta_{\mathrm{h}}=0.03528 \mathrm{~m}$

$>$ To calculate the maximum displacement for liquefiable soil.

The liquefied soil is conservatively assumed to have approximately zero stiffness $(\mathrm{Esd}=0)$ for determination of inertial load.

The fixity depth is

$\mathrm{T}_{\mathrm{u}}=\left(\mathrm{E}_{\mathrm{p}} \mathrm{I}_{\mathrm{p}} / \mathrm{K}\right)^{0.2}$

$\mathrm{T}_{\mathrm{u}}=\left(953.75 \times 10^{3} / 200\right)^{0.2}=5.44$

If the depth of the liquefied layer is less than $\mathrm{T}_{\mathrm{u}}$, the fixity depth is given as $2.2 \mathrm{~T}_{\mathrm{u}}$.

If the liquefied layer is deeper than $\mathrm{T}_{\mathrm{u}}$, the fixity depth is 1.8 $\mathrm{T}_{\mathrm{u}}$.

$\mathrm{L}_{\mathrm{f}}=1.8 \times 5.44=9.79 \mathrm{~m}$

The lateral stiffness of a single pile is

$\mathrm{K}_{\mathrm{h}}=12 \mathrm{EI} /\left(\mathrm{L}+\mathrm{L}_{\mathrm{f}}\right)^{3}$

$\mathrm{K}_{\mathrm{h}}=\left(12 \times 953.75 \times 10^{3}\right) /(0+9.79)^{3}$

$\mathrm{K}_{\mathrm{h}}=12.183 \mathrm{KN} / \mathrm{m}$

The natural frequency of the pile is

$f_{p}=(1 / 2 \Pi)\left(\sqrt{ }\left(4 \times 12.183 \times 10^{3} / 2550\right)\right)=0.696 \mathrm{~Hz}$

The natural period is

$1 / 0.696=1.436$

From fig $6.3^{[17]}$ for a time period is 1.2 seconds, the spectral acceleration is $1.2 \mathrm{ag}_{\mathrm{g}}$

$1.2 \times 0.2 \times 9.81=2.35$

The horizontal inertial load on the pile will be

$\mathrm{H}=2550 \times 2.35=6003.72 \mathrm{KN}$

The peak horizontal displacement during the inertial response of the pile is

$\delta_{\mathrm{h}}=\mathrm{H} / 4 \mathrm{~K}_{\mathrm{h}}=6003.72 / 4 \times 12.183 \times 10^{3}$

$\delta_{\mathrm{h}}=0.12319 \mathrm{~m}$

\section{Step 2: Building the model and analysis}

Preprocessing: The model is built in preprocessor stage. The major steps in processing are given below:

- Define volume

- Define element type and material / geometric properties 20 node brick elements are used to built the model and combination spring- damper14 is used and material properties used are young's modulus 27386 x $103 \mathrm{KN} / \mathrm{m} 2$, poison's ratio 0.3 and density $25 \mathrm{KN} / \mathrm{m} 3$.

- Mesh the volumes

- Applying the boundary conditions A fixed condition is provided at bottom and springs with stiffness are applied around the pile.

- Solution - Apply 2550KN load at the top and horizontal load is provided at left side at each $2 \mathrm{~m}$ depth.

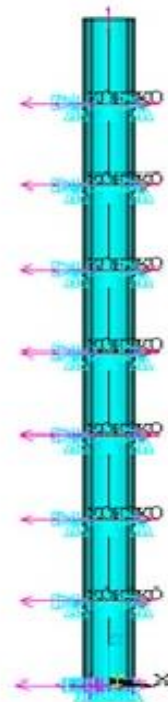

Figure 2. Pile Model with Meshing \& loading Conditions

Step 3: Reviewing the Results (post processing): The results of the static analysis can be seen in post processing phase of ANSYS.

\section{Step 4: Verification and validation}

It is imperative to do some checks to make sure that the numerical results are accurate. Numerical results can either be compared directly to empirical data or they may be compared to theory.

Verification of Maximum Total Displacement

The ANSYS results will be verified by comparing them to the results obtained using Winkler spring approach in the preanalysis. The ANSYS simulation outputted $0.035817 \mathrm{~m}$ for the total displacement of the beam at $\mathrm{x}=16 \mathrm{~m}$ for nonliquefiable soil while the calculation from the pre-analysis yielded $0.03528 \mathrm{~m}$. The ANSYS simulation outputted $0.13802 \mathrm{~m}$ for the total displacement of the beam at $\mathrm{x}=16 \mathrm{~m}$ for $4 \mathrm{~m}$ dense sand as liquefiable soil while the calculation from the pre analysis yielded $0.12319 \mathrm{~m}$. The ANSYS results very

closely match the calculations from the pre-analysis, thus the simulation has been verified.

Table 3. Verification of Maximum Total Displacement

\begin{tabular}{|ll|l|l|}
\hline Results(m) & Analytical (m) & ANSYS(m) \\
\hline $\begin{array}{l}\text { Displacement for } \\
\text { Nonliquefiable soil }\end{array}$ & 0.03528 & 0.035817 \\
\hline $\begin{array}{l}\text { Displacement for } \\
\text { liquefiable soil }\end{array}$ & 0.12319 & 0.13802 \\
\hline
\end{tabular}

\section{RESULTS AND DISCUSSIONS}

In this chapter the results obtained for different concrete piles are presented. An effort has been also made to study the behavior of concrete pile by varying the soil layers 
and studied the effect of liquefaction on piles. In the present study, the analysis is done for M30 grade of concrete pile having $1 \mathrm{~m}$ diameter and $16 \mathrm{~m}$ length using ANSYS software. The parameters considered are different soil layers such as dense sand, loose sand and effect of liquefaction.

\subsection{Effects of non liquefiable soil layers}

In the analysis, finite element 3D models are created for single layer and two layers of soil. Single layer consist of $16 \mathrm{~m}$ length of dense sand and two layers consist of $8 \mathrm{~m}$ dense sand at the bottom and $8 \mathrm{~m}$ loose sand at the top as shown in fig 3. 3D finite element analysis is performed, after applying the loading conditions to the final model and stiffness at each $2 \mathrm{~m}$ depth around the pile.

The result shows that the total displacement increases with respect to depth of pile from bottom to top of the concrete pile. The maximum displacement is at the ground level and it is zero at the $16 \mathrm{~m}$ length because it is assumed as fixed at the bottom. The curves shows in fig 4 analytical and ANSYS results, the ANSYS results are near to the analytical results and zero at the bottom. The result of these analyses shows a significant difference in the displacements due to different soil layers and stiffness.

Fig 5 shows displacements for two layers nonliqefiable soil, the analytical results are compared with ANSYS results, the results are almost same but the maximum displacement of analytical result is $21 \%$ less than ANSYS results.

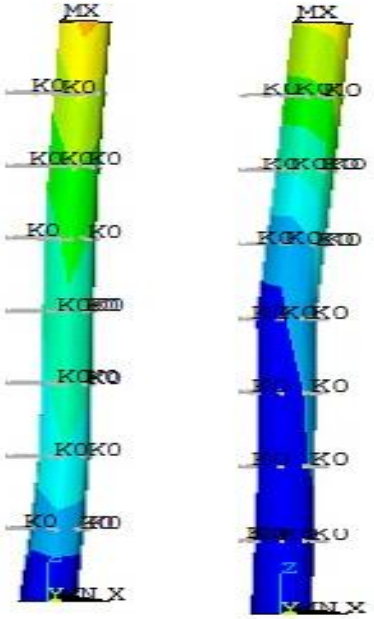

Figure3. 3D Model of Pile for Single and two Layers Soil

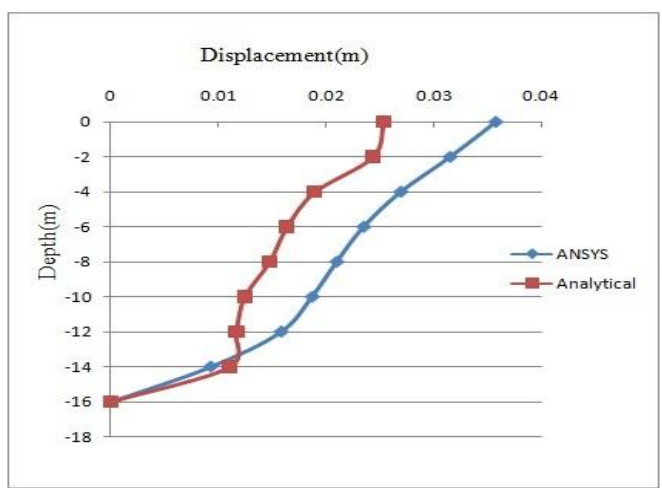

Figure4.Displacements for one Layer Nonliqefiable Soil

\begin{tabular}{|c|c|c|c|c|c|c|c|c|c|c|c|}
\hline SI No & Depth & Tu & Lf & Kh & fp & N P & $\mathbf{A}$ & Accln & $\mathbf{H}$ & סh-Analytical & Sh-Model \\
\hline 1 & 0 & 5.44103 & 9.79385 & 12.183 & 0.69611 & 1.436554 & 1.2 & 2.3544 & 6003.72 & 0.12319835 & 0.13802 \\
\hline 2 & 2 & 5.44103 & 9.79385 & 12.183 & 0.69611 & 1.436554 & 1.2 & 2.3544 & 6003.72 & 0.12319835 & 0.134307 \\
\hline 3 & 4 & 5.44103 & 9.79385 & 12.183 & 0.69611 & 1.436554 & 1.2 & 2.3544 & 6003.72 & 0.12319835 & 0.128557 \\
\hline 4 & 6 & 5.44103 & 9.79385 & 12.183 & 0.69611 & 1.436554 & 1.2 & 2.3544 & 6003.72 & 0.12319835 & 0.117063 \\
\hline 5 & 8 & 5.44103 & 9.79385 & 12.183 & 0.69611 & 1.436554 & 1.2 & 2.3544 & 6003.72 & 0.12319835 & 0.096474 \\
\hline 6 & 10 & 2.5412 & 4.57416 & 9.68008 & 0.6205 & 1.6116116 & 1.1 & 2.1582 & 5503.41 & 0.142132418 & 0.066544 \\
\hline 7 & 12 & 2.5412 & 4.57416 & 18.1569 & 0.84981 & 1.1767355 & 1.5 & 2.943 & 7504.65 & 0.103330541 & 0.0352016 \\
\hline 8 & 14 & 2.5412 & 4.57416 & 40.2806 & 1.26575 & 0.7900449 & 2.13 & 4.17906 & 10656.6 & 0.066139802 & 0.0104063 \\
\hline 9 & 16 & 0 & 0 & 0 & 0 & 0 & 0 & 0 & 0 & 0 & 0 \\
\hline
\end{tabular}

Table 4. Displacement of concrete pile

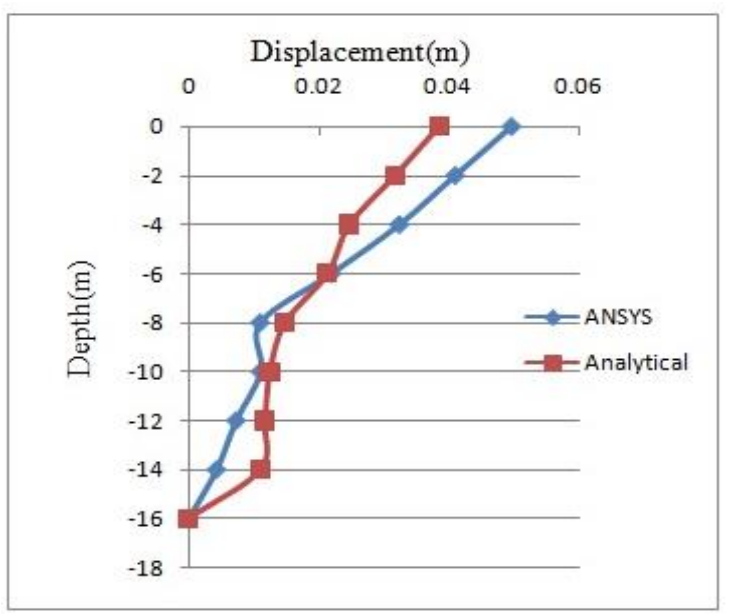

\subsection{Effects of liquefiable soil layers}

In the analysis, finite element 3D models are created considering different soil layers as liquefiable soil. 3D finite element analysis is performed, after applying the loading conditions to the final model and stiffness at each $2 \mathrm{~m}$ depth around the pile. Figure 6. Shows the displacement of the pile having single layer of soil that is dense sand $8 \mathrm{~m}$ length from the bottom of pile to ground is considered as liquefiable soil.

Figure5.Displacements for two Layer Nonliqefiable Soil 


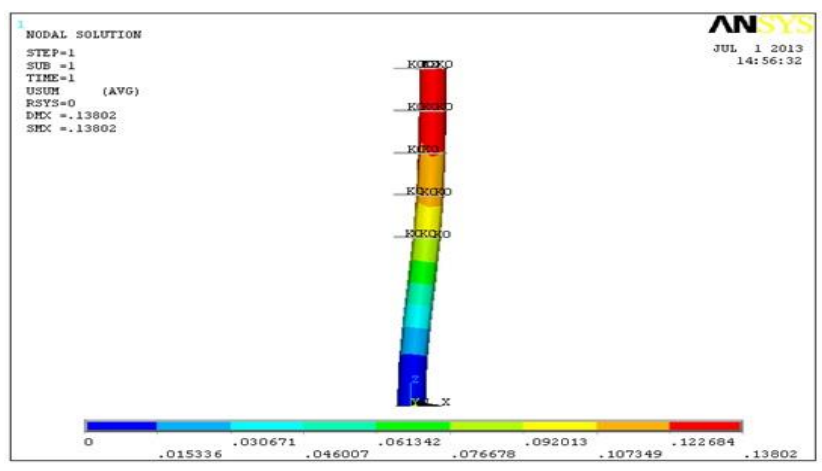

Figure6. 3D Model of Pile with 8m Liquefaction from the bottom for dense Layer Soil

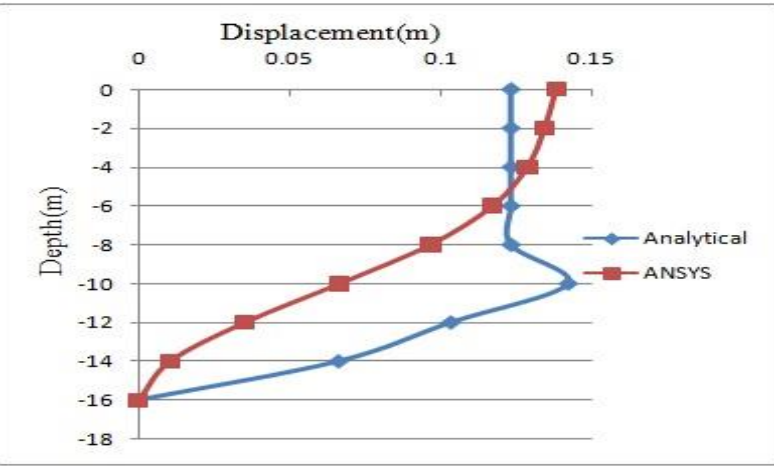

Figure7. Displacements for $8 \mathrm{~m}$ dense layer and liquefaction from the bottom

\subsubsection{Discussion}

To see the effect of liquefiable soil layers, the total displacement of the pile versus depth of the pile is presented in figures 7. The curves indicate that the total displacement increases with respect to depth of pile from bottom towards top of the concrete pile. The analytical results are compared with ANSYS results, the results are almost same but the maximum displacement of analytical result is $30 \%$ less than ANSYS results. The analytical curve is linearly decreasing up to $8 \mathrm{~m}$ depth after that increasing slightly and zero at the bottom because of fixity. The displacement of concrete pile is more for which is having liquefiable soil compared to nonliquefiable soil because when liquefaction takes place soil loses its strength and stiffness therefore such piles will have more displacement.

\subsection{Comparisons of model results for liquefiable and} nonliquefiable soil layers

The Type of concrete piles and its descriptions are given in table 5.

Table 5. Types and description of piles

\begin{tabular}{|l|l|}
\hline Type & Description \\
\hline H1 & Control model Non liquefiable dense sand \\
\hline A & $16 \mathrm{~m}$ Dense sand and top $8 \mathrm{~m}$ is liquefiable soil \\
\hline B & $16 \mathrm{~m}$ Dense sand and bottom $8 \mathrm{~m}$ is liquefiable soil \\
\hline C & $16 \mathrm{~m}$ Loose sand and top $8 \mathrm{~m}$ is liquefiable soil \\
\hline D & $\begin{array}{l}\text { 8m Loose sand and } 8 \mathrm{~m} \text { dense sand, } 4 \mathrm{~m} \text { loose sand is } \\
\text { liquefiable soil }\end{array}$ \\
\hline E & $\begin{array}{l}\text { 8m Loose sand and } 8 \mathrm{~m} \text { dense sand, } 4 \mathrm{~m} \text { dense sand is } \\
\text { liquefiable soil }\end{array}$ \\
\hline
\end{tabular}

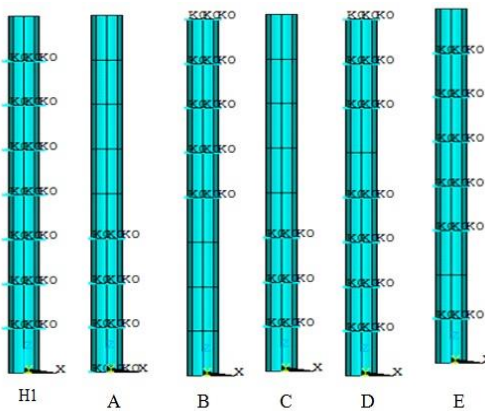

Figure8. Model results of concrete pile for liquefiable and nonliquefiable soils

Table 6. Model results of concrete pile for liquefiable soils

\begin{tabular}{|c|c|c|c|c|c|c|}
\hline \multirow{2}{*}{ Depth } & Non Liq & \multicolumn{5}{|c|}{ Liquefiable soil layers } \\
\cline { 2 - 7 } & H1 & A & B & C & D & E \\
\hline 0 & 0.0357 & 0.36501 & 0.13802 & 0.15095 & 0.14025 & 0.06458 \\
\hline-2 & 0.03146 & 0.31603 & 0.13431 & 0.13311 & 0.11472 & 0.05405 \\
\hline-4 & 0.02688 & 0.26711 & 0.12856 & 0.11538 & 0.08696 & 0.04338 \\
\hline-6 & 0.02344 & 0.21831 & 0.11706 & 0.09785 & 0.05858 & 0.03938 \\
\hline-8 & 0.02095 & 0.16971 & 0.09647 & 0.08062 & 0.04251 & 0.04104 \\
\hline-10 & 0.01867 & 0.12154 & 0.06654 & 0.06415 & 0.04367 & 0.0422 \\
\hline-12 & 0.01578 & 0.07282 & 0.0352 & 0.04558 & 0.03866 & 0.03154 \\
\hline-14 & 0.00925 & 0.02643 & 0.01041 & 0.02073 & 0.01847 & 0.01483 \\
\hline-16 & 0 & 0 & 0 & 0 & 0 & 0 \\
\hline
\end{tabular}

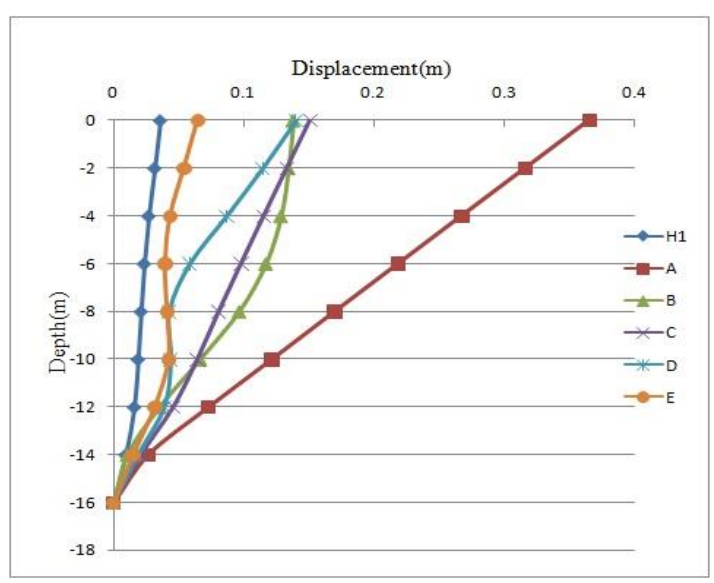

Figure9. Model results of concrete pile for liquefiable soils

To see the effect of liquefiable soil layers, the total displacement of the pile versus depth of the pile is presented in figure 9. Comparing the liquefiable soil models A, B, C, D and E with Control model Non liquefiable dense sand model $\mathrm{H} 1$, the model A has $90 \%$ more displacement than the control model H1 similarly model B- $74 \%$, model C- $76 \%$, model D- $75 \%$ and model E- $80 \%$ displacement respectively. The displacement of concrete pile is more for which is having liquefiable soil compared to nonliquefiable soil because when liquefaction takes place soil loses its strength and stiffness therefore such piles will have more displacement. Among all the curves model A has maximum displacement and it is linearly decreasing with respect to depth but remaining curves are not linear, the results for model B and model $\mathrm{C}$ are almost same. 


\section{CONCLUSIONS}

After compiling and analyzing the results from each analysis, the following conclusions can be made.

- The total displacements are increasing with respect to the depth of pile from bottom towards top of concrete pile in both liquefiable and nonliquefiable soil layers.

- The concrete piles in nonliquefiable soil layers, the analytical results are less than model results and as the depth increases the values are almost same.

- The concrete piles in liquefiable soil layers, as the depth increases from top to bottom of pile the displacement of pile decreases.

- By comparing the results of concrete pile under liquefiable \& nonliquefiable soil layers it can be seen that liquefaction of the upper soil layer, reduces the lateral stiffness of the foundation substantially, lengthens the natural period of the foundation, reduces acceleration at the top of the foundation, and increases the lateral response of the foundation substantially.

- Comparing the liquefiable soil models A, B, C, D and E with Control model $\mathrm{H} 1$, the displacement in other models are having $75 \%$ to $90 \%$ more than the control model displacement.

- The structural load and the surrounding soil stiffness does have a significant impact on the overall behavior of the pile under the liquefiable \& nonliquefiable soil layers and must be considered when designing a pile under similar conditions.

\section{REFERENCES}

[1] Subhamoy Bhattacharya, "Safety Assessment Of Existing Piled Foundations In Liquefiable Soils Against Buckling Instability", ISET Journal of Earthquake Technology, Technical Note, Vol. 43, No. 4, December 2006, pp. 133-147.

[2] MiskoCubrinovski, Kenji Ishihara, "Simplified Analysis Of Piles Subjected To Lateral Spreading: Parameters And Uncertainties", 4th International Conference On Earthquake Geotechnical Engineering, June 2007 Paper No. 1385.

[3] Hayden J. Bowen and MiskoCubrinovski, "Pseudo-Static Analysis of Piles in Liquefiable Soils: Parametric Evaluation of Liquefied Layer Properties", Bulletin of the New Zealand Society for Earthquake Engineering, Vol. 41, No. 4, December 2008.

[4] D. S. Liyanapathirana and H. G. Poulos, "Pseudostatic Approach for Seismic Analysis of Piles in Liquefying Soil", Journal of Geotechnical and Geoenvironmental Engineering (C) ASCE / December 2005.

[5] Joseph E. Bowles, "Foundation Analysis and Design".

[6] GopalMadabhushi, Jonathan Knappett\& Stuart Haigh "Design of Pile Foundations in Liquefiable Soils".

[7] Eurocode 8: "Design of structures for earthquake resistance - Part 5: Foundations, retaining structures and geotechnical aspects", December 2003. 